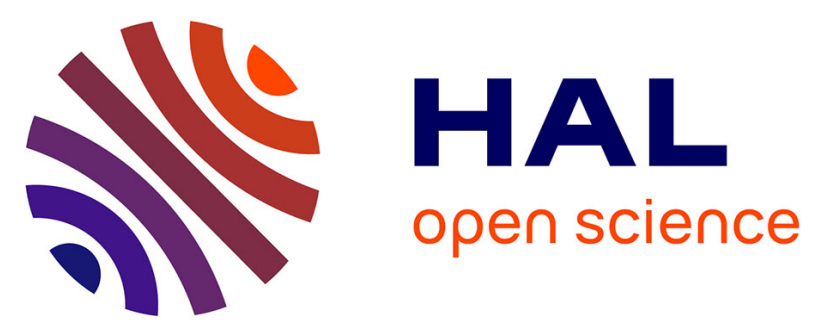

\title{
Behavioral cardiovascular risk factors in HIV-infected people in France: diversity of profiles across groups requires an urgent and tailored preventive approach \\ Laure Tron, France Lert, Bruno Spire, Rosemary Dray-Spira
}

\section{- To cite this version:}

Laure Tron, France Lert, Bruno Spire, Rosemary Dray-Spira. Behavioral cardiovascular risk factors in HIV-infected people in France: diversity of profiles across groups requires an urgent and tailored preventive approach. Epidemiology and Public Health = Revue d'Epidémiologie et de Santé Publique, 2018, epub ahead of print. 10.1016/j.respe.2018.10.006 . inserm-01963753

HAL Id: inserm-01963753

https://www.hal.inserm.fr/inserm-01963753

Submitted on 21 Dec 2018

HAL is a multi-disciplinary open access archive for the deposit and dissemination of scientific research documents, whether they are published or not. The documents may come from teaching and research institutions in France or abroad, or from public or private research centers.
L'archive ouverte pluridisciplinaire HAL, est destinée au dépôt et à la diffusion de documents scientifiques de niveau recherche, publiés ou non, émanant des établissements d'enseignement et de recherche français ou étrangers, des laboratoires publics ou privés. 


\title{
Behavioral cardiovascular risk factors in HIV-infected people in France: diversity of profiles across groups requires an urgent and tailored preventive approach
}

\begin{abstract}
:
Background. Among people living with HIV, cardiovascular risk could be markedly reduced through lifestyle improvement. However, to date behavioral cardiovascular risk factors (other than tobacco smoking) have been poorly investigated among them. Additionally, although co-occurrence of risk factors might amplify the deleterious effects of each risk factor, little is known about such risk factors clustering in this population. We aimed to examine levels, determinants and clustering of the major behavioral cardiovascular risk factors in the French HIV-infected population, in order to better target individuals with high risk profiles.

Methods. The ANRS-Vespa2 survey was conducted among a national representative sample of HIV-infected people followed at hospital in France in 2011. Frequency and cooccurrence of tobacco smoking, alcohol intake, low physical activity and obesity were assessed in the HIV-infected population, overall and in each of the distinctive socioepidemiological group composing it (men who have sex with men, intravenous drug users, sub-Saharan African migrants, non-African heterosexuals). Individual characteristics associated with each of these indicators were investigated using multivariable Poisson regression models.
\end{abstract}

Results. The 2,537 participants (median time since HIV-diagnosis: 12 years) included $39.4 \%$ men who have sex with men, $11.0 \%$ intravenous drug users, $23.5 \%$ sub-Saharan African migrants and $26.1 \%$ non-African heterosexuals. Overall, $29.4 \%$ were regular smokers, $13.8 \%$ were heavy drinkers, $14.8 \%$ lacked physical activity and $8.6 \%$ were obese. Half of the participants reported at least one risk factor with co-occurrence observed in $13.8 \%$ of the sample. However, those figures varied markedly across the groups. Main risk factors 
profiles were 1) regular smoking, heavy drinking, low physical activity alone or combined among intravenous drug users and men who have sex with men, 2) obesity and low physical activity usually alone among sub-Saharan African migrant women, 3) occurrence of the 4 risk factors separately or sometimes combined among sub-Saharan African migrant men and non-African heterosexuals. These risk factors were correlated with lower socioeconomic status and poorer health status.

Conclusions. Those findings highlight the need to focus on all behavioral cardiovascular risk factors and co-occurrence (and not only on tobacco smoking) in HIV-infected people and to implement preventive approach tailored to the specific needs of the different socioepidemiological groups.

Keywords: HIV infection. Cardiovascular risk factors. Tobacco smoking. Alcohol intake. Lifestyle. France.

\section{Résumé:}

Position du problème. Améliorer l'hygiène de vie pourrait réduire le risque cardiovasculaire des personnes séropositives pour le VIH. Cependant, hormis le tabac, les facteurs de risque cardiovasculaire comportementaux ont été peu étudiés dans cette population, de même que le cumul de plusieurs facteurs de risque (bien que susceptible d'amplifier l'effet de chaque facteur). Notre objectif était d'étudier la fréquence, le cumul et les déterminants des principaux facteurs de risque cardiovasculaire comportementaux dans la population séropositive française, afin de mieux identifier les individus particulièrement à risque.

Méthodes. Ces travaux reposent sur l'enquête ANRS-Vespa2 conduite auprès d'un échantillon représentatif des personnes séropositives suivies à l'hôpital en France en 2011. La fréquence et le cumul du tabagisme, de l'alcoolisme, d'une faible activité physique et de l'obésité ont été estimés, globalement et au sein des groupes socio-épidémiologiques 
composant la population séropositive (hommes ayant des rapports sexuels avec des hommes, usagers de drogues injectables, migrants originaires d'Afrique sub-Saharienne, hétérosexuels non originaires d'Afrique sub-saharienne). Des modèles de régression de Poisson visaient à identifier les facteurs associés à chaque facteur de risque.

Résultats. Les 2537 participants (durée médiane depuis le diagnostic du VIH : 12 ans) incluaient $39,4 \%$ d'hommes ayant des rapports sexuels avec des hommes, $11,0 \%$ d'usagers de drogues, 23,5\% de migrants africains, 26,1\% d'hétérosexuels. Globalement, $29.4 \%$ étaient fumeurs réguliers, $13.8 \%$ de gros consommateurs d'alcool, $14.8 \%$ manquaient d'activité physique, $8.6 \%$ étaient obèses. La moitié des participants présentaient au moins un facteur, $13,8 \%$ en cumulaient plusieurs -avec d'importantes variations selon le groupe. Les principaux profils de facteurs de risque étaient le tabac régulier, l'alcoolisme, une faible activité physique, seuls ou cumulés, chez les usagers de drogues et les hommes ayant des rapports sexuels avec des hommes ; l'obésité et une faible activité physique généralement seuls chez les femmes africaines ; les 4 facteurs seuls ou parfois cumulés chez les migrants africains et les hétérosexuels. Un moins bon état de santé et un faible statut socioéconomique étaient associés aux facteurs de risque.

Conclusions. Il est urgent d'intervenir sur l'ensemble des facteurs de risque cardiovasculaire comportementaux et leur cumul dans la population séropositive, à l'aide d'approches adaptées aux besoins spécifiques des différents groupes socio-épidémiologiques.

Mots clefs : Infection au VIH. Facteurs de risque cardiovasculaire. Tabagisme. Consommation d'alcool. Mode de vie. France. 


\section{Introduction}

In the combined antiretroviral therapy (cART) era, life expectancy of people living with HIV (PLWHIV) has considerably increased and HIV-infection has shifted to a chronic disease [1]. Following these major changes in the epidemic in Western countries, AIDSrelated conditions have been constantly decreasing while the burden of non-AIDS-related and age-related comorbidities is of growing concern [2]. In particular, cardiovascular diseases now represent one of the leading causes of death among PLWHIV, steadily increasing in recent years [2, 3], occurring earlier, more frequently and possibly with different patterns compared to the general population [4]. This probably results from an array of concurrent causes including HIV-infection (CD4 depletion, immune activation, chronic inflammation, viral proteins $[4,5]$ ), cART (mostly through metabolic and lipid abnormalities [6]), as well as a higher exposure to cardiovascular risk factors $[4,7,8]$.

Consequently, in order to prevent cardiovascular events during the HIV-infection, it is recommended to screen and manage risk factors including both biological (diabetes, hypertension, dyslipidemia) and behavioral ones (tobacco and alcohol consumption, lack of physical exercise, obesity). Biological risk factors are frequent in PLWHIV $[4,7,8]$ and need to be treated and monitored following general population guidelines and accounting for HIVinfected individuals' specific needs (drug-drug interactions with cART, increased toxicity/side effects) [9]. As regards to behavioral cardiovascular risk factors, tobacco smoking is certainly the most concerning one among PLWHIV [10-12]. Furthermore, heavy drinking $[12,13]$ and lack of physical activity $[14,15]$ have also been associated with poorer cardiovascular health, as well as a high body mass index (BMI) [16] which is a relatively new issue in HIVinfected people from Western countries, among whom thinness was the major problem until cART advent $[17,18]$. Elevated rates of tobacco smoking $(30-60 \%[8,11,19-21])$, heavy 
alcohol use $(10-30 \%[13,22])$, lack of exercise $(15-70 \%[8,23,24])$ and obesity $(9-33 \%[8$, $17,18,25,26])$ have been reported in previous studies, with marked variability resulting from different assessment methods, definitions or individuals' characteristics. Those few previous studies have shown some limitations to rigorously inform on those risk factors since: 1) they overall rely on small or convenient samples not representative of the HIV-infected population, 2) none have provided results separately for the different socio-epidemiological groups constituting this population (although they have very different socio-demographic, economic and lifestyle profiles), and 3) some studies provide risk factors prevalence as part of a population description for other analyses and thus do not provide detailed information nor analyses of the risk factors determinants. Moreover, it has been suggested that unhealthy behaviors often coexist $[21,27,28]$ and that the risk of morbidity/mortality increases with each additional risk factor [27], possibly in a multiplicative rather than an additive way [29]. In the general population, studies have investigated the combination of behavioral cardiovascular risk factors [27]. However, to our knowledge, most previous studies among PLWHIV have focused on risk factors individually [8, 21] and only one has examined cumulative exposure [28] but both to behavioral and biological risk factors.

Behavioral risk factors are potentially modifiable and cardiovascular risk may be reduced through lifestyle ameliorations and smoking/alcohol cessation [9], but interventions generally result in modest improvements [7, 30-32]. It is needed to better understand their occurrence in HIV-infected people, in order to target those with high risk profiles and to propose appropriate actions/guidelines to improve PLWHIV engagement in healthier lifestyle. Our objectives were to precisely describe the frequency, determinants and cooccurrence of the major behavioral cardiovascular risk factors among HIV-infected people. 


\section{Methods}

\section{Sources of data}

The ANRS-Vespa2 study is a national representative cross-sectional survey conducted in France (April 2011-January 2012), primarily aimed at assessing the socioeconomic conditions and health outcomes of PLWHIV $[19,33]$ and approved by the French National Commission for Data Protection and Liberties (CNIL). It was conducted among 73 out-patient departments randomly selected among all hospital with HIV units in metropolitan France. Patients aged $\geq 18$ years, living in France for $\geq 6$ months and diagnosed with HIV-infection for $\geq 6$ months were eligible for inclusion and were randomly invited to participate by their physician, according to the order of their appointment. A total of 3,022 patients were included in the study. After signing an informed consent, participants answered a face-to-face standardized questionnaire administered by a trained interviewer, including detailed questions about socio-demographic and economic situation, health behaviors and healthcare use. Clinical and laboratory data were documented from medical records. A total of 2,537 participants also filled in a voluntary self-administered questionnaire on health behaviors and quality of life. Individual weights were computed to account for unequal probability of sampling and for characteristics associated with non-participation, both for the total sample $(\mathrm{N}=3,022)$ and for the subsample who filled in the self-reported questionnaire $(\mathrm{N}=2,537)[33]$.

Variables of interest

In the main questionnaire, participants were asked about their tobacco consumption [19]. Tobacco smoking status was defined as never smokers, past smokers, and current smokers including occasional smokers ( $<1$ cigarette/day) and regular smokers $(\geq 1$ cigarette/day). Main questionnaire included questions about frequency of alcohol intake, number of standard drink per occasion and frequency of having $\geq 6$ drinks/occasion. We 
categorized the drinking status as abstinent (those who never drink), low/moderate drinking ( $<14$ drinks/week for women, $<21$ drinks/week for men and having $\geq 6$ drinks/occasion less than monthly), and heavy drinking ( $\geq 14$ drinks/week for women, $\geq 21$ drinks/week for men or having $\geq 6$ drinks/occasion at least monthly) [13]. The self-administered questionnaire included the French validated version of the Baecke physical activity questionnaire [34, 35]. It comprised 21 items, used to calculate 3 subscores (range: 1-5 points) regarding the past 12 months physical activity. The first subscore investigated physical activity at work: sitting, walking, carrying heavy loads, perspiring, intensity compared to other people (subscore value being 1 if no job or daily occupation was reported, as recommended by the guidelines for construction of Baecke index [34, 35]). The second subscore evaluated physical exercise during sports activities: intensity, frequency, duration, perspiring, intensity compared to other people. Finally, the third subscore measured physical activity during leisure time: time spent watching TV, walking, cycling, means of locomotion. The 3 subscores were summed to calculate the global physical activity score (range: 3-15 points, higher score representing higher level of physical activity). The global score was then classified into low (<6 points), moderate (6-9 points) and high ( $\geq 9$ points) physical activity level [34]. Information on weight and height from medical records allowed us to calculate and categorize BMI according to the definitions from the World Health Organization (WHO) [36]: underweight (BMI $\left.\left[\mathrm{kg} / \mathrm{m}^{2}\right]<18.5\right)$, normal weight $(18.5-25)$, overweight $(25-30)$, obesity $(\geq 30)$. In addition, we constructed indicators combining the four risk factors: regular smoking, heavy drinking, low physical activity and obesity. We calculated the number of risk factors occurring for each individual (range: 0-4) and we created a variable identifying all possible combinations out of a total of 16 possible combinations (e.g.: none, regular smoking only, obesity + low physical activity, regular smoking + heavy drinking + low physical activity, all 4 risk factors etc.). It is worth noting that these indicators on risk factors clustering were derived strictly for 
descriptive purpose and do not aim at quantifying a risk exposure (in which case it would be necessary to account for the different contribution of these risk factors to the cardiovascular risk).

The ANRS-Vespa2 study also included data on socio-demographic characteristics: age, gender, country of birth, household composition (single/in a couple, with/without children) and educational level (primary school, middle school, high school, college $\leq />2$ years). Available information regarding psychosocial factors was the number of relatives and friends and consumption of illegal substance over the past month (including cannabis). In addition, regarding psychological trait, "time-related preferences" (future-oriented attitudes/planning horizon) were assessed using 4 standard questions. A score was derived from these questions and categorized according to its tertiles of distribution in the studied population into low, neutral and high future outlook [37]. Information on HIV-infection characteristics from medical records included date of diagnosis and transmission group. In the self-administered questionnaire, a 22-item, validated HIV symptom index assessed the frequency of HIV symptoms and their perceived level of disturbance over the past 4 weeks (i.e. : no, low, medium, high disturbance) [38].

HIV-infected participants were classified into mutually exclusive socioepidemiological groups [33]: i) people ever infected through drug injection, past or current intravenous drug users, (IDU) regardless of sexual orientation or geographic origin, ii) nonIDU men who have sex with men (MSM) regardless of geographic origin, iii) non-IDU heterosexual migrants originating from sub-Saharan Africa (SSA) and iv) non-IDU nonAfrican heterosexual men and women.

Statistical analyses 
We restricted the analyses to the 2,537 participants who answered all questionnaires - since outcomes from both the main questionnaire and the self-reported (facultative) questionnaire were used in the analyses.

First, we described individual and combined distribution of the four behavioral cardiovascular risk factors (regular smoking, heavy drinking, low physical activity and obesity) overall and across the socio-epidemiological groups. In a second step, factors associated with exposure to each risk factor were investigated using univariable and multivariable Poisson regression models with robust variance. In the univariable analyses, we included socio-demographic characteristics: age, socio-epidemiological group, household composition and educational level (which seemed to be the most relevant indicator to account for socio-economic status over time in studies on behavioral risk factors, according to exploratory analyses and to the literature). The univariable analyses also included psychosocial characteristics (number of friends and relatives, time preferences, illegal substance use), presence of other behavioral cardiovascular risk factors and HIVinfection characteristics (date of diagnosis, disturbance from at least one HIV symptom). Multivariable models included all covariates associated in the univariable analyses with a Pvalue $<0.20$, and were systematically adjusted for age.

Missing data were observed for illegal substance use $(0.1 \%)$, disturbance from HIV symptoms (1.7\%), BMI (6.5\%), and physical activity (47.5\% on the global score, between 0 $25 \%$ for each item, with $\leq 10 \%$ in $19 / 21$ items). Non-response for physical activity was more frequent among individuals aged $<40$ or $>55$ years old, SSA migrants, those living with a partner and children, those with a low educational level and those unemployed. Consequently, we faced substantial loss of participants in the analyses and potential nonresponse biases. Therefore, we performed multiple imputations by chained equations to handle missing data, running 60 imputed datasets with 20 cycles [39-41]. All the variables 
used in the analyses were introduced in the imputation model. For variables based on several individual items (e.g. physical activity score, BMI), we imputed individually each item used to derive the variable of interest, as recommended by the guidelines for multiple imputation [39-41]. Estimates were pooled according to Rubin's rules [40]. Sensitivity analyses on the non-imputed dataset (complete cases analysis) were performed to compare and discuss our main results.

In all analyses, data weighting and survey design were accounted for, so that the estimates would be representative of the whole HIV-infected population followed at hospital in France in 2011 [33]. Statistical analyses were carried out using STATA/SE12 (Stata Corporation, College Station, TX).

\section{Results}

Studied sample consisted in 2,537 HIV-infected individuals (table 1), of whom $11.0 \%$ were IDU, 39.4\% were MSM, $23.5 \%$ were SSA migrants and $26.1 \%$ were non-African heterosexuals. Median age was 47 years (interquartile range: $40-54$ ). Median time since HIV-diagnosis was 12 years (interquartile range: 6-19). One third attained educational level higher than high school. Recent illegal substance use was reported by $14.4 \%$ of the sample with marked variability across the different groups (almost half of the IDU vs. practically no use among SSA migrants). Most of the sample reported disturbance from at least one HIV symptom $(66.4 \%)$.

Levels and combination of behavioral cardiovascular risk factors

Overall, $40.8 \%$ were never smokers, $23 \%$ were past smokers and $36.2 \%$ were current smokers (occasional: 6.8\%; regular: $29.4 \%$ ). High variability was observed across the groups $(p<0.001)$ with more than two thirds of the IDU being regular smokers compared 
to less than 1 out of 10 of the SSA migrants (figure 1). Almost one third of the population was alcohol abstinent. Mean number of drinks/week was 4.1 and $13.1 \%$ of the sample reported drinking $\geq 6$ drinks/occasion at least monthly. Heavy drinking occurred in $13.8 \%$ overall, with lower rates among women. Mean global physical activity score was 7.5 (ranging from 6.6 among IDU women to 7.7 among MSM and non-African heterosexual men). Overall, $14.8 \%, 65.2 \%$ and $19.9 \%$ had low, moderate and high level of physical activity respectively. IDU and non-African women were particularly prone to low physical activity. Overall, $6 \%, 58.2 \%, 27.2 \%$ and $8.6 \%$ were underweight, in normal weight range, overweight and obese respectively, with notable variability across the groups $(p<0.001) . M S M$ and IDU men were mostly in normal weight range $(69.0 \%$ and $74.3 \%$ respectively) while $27.9 \%$ of IDU women were underweight, SSA migrants were predominantly overweight (men: $46.4 \%$; women: $36.2 \%)$ or obese (men: $12.6 \%$; women: $20.9 \%$ ), over one third $(36.5 \%)$ of nonAfrican heterosexual men were overweight and $10.6 \%, 22.1 \%$ and $13.0 \%$ of non-African heterosexual women were underweight, overweight and obese respectively.

Overall, $51.1 \%$ reported at least one behavioral cardiovascular risk factor and $13.8 \%$ presented at least 2 risk factors. A high variability in those frequencies was observed across the groups ( $p<0.001$ ), with $27.8 \%$ of IDU women having $\geq 2$ risk factors and $62.0 \%$ of SSA migrant women reporting none. Overall (figure 2), main profile was regular smoking with no other risk factor $(17.7 \%)$, followed by low physical activity alone $(7.4 \%)$, obesity alone (6.2\%), heavy drinking alone (6.1\%), regular smoking with heavy drinking (5.2\%) and low physical activity with regular smoking (4.4\%), with high variability across the groups $(p<0.001)$. Results for MSM were relatively close to the overall profile (with a lower frequency of obesity). The most represented patterns among IDU were tobacco smoking alone observed in almost half of them, as well as low physical activity and heavy drinking alone or combined with regular smoking. Among SSA migrants, all four risk factors occurred mostly 
alone, especially obesity and low physical activity. Non-African heterosexuals had all four risk factors alone, especially regular smoking which was also combined with heavy drinking and low physical activity.

Factors associated with each behavioral cardiovascular risk factor

Regular smoking was more likely to be reported by IDU (men: adjusted Prevalence Rate Ratio (aPRR): 1.24, 95\% Confidence Interval (95\%Cl): [1.02-1.51]; women: 1.28 [1.021.60]) vs. MSM, those with a low educational level (middle school: 1.31 [1.07-1.60]; $\leq 2$-year university degree: 1.27 [1.00-1.61]) vs. >2-year university degree, illegal drug users (2.12 [1.81-2.49]) vs. non-users, heavy drinkers (1.36 [1.13-1.64]) vs. abstinent, those with low (1.57 [1.32-1.88]) or neutral $(1.46[1.22-1.75])$ vs. high future outlook and those reporting disturbance from HIV symptoms (1.19 [1.02-1.39]) vs. those who did not, according to the multivariable analysis in table 2 . In contrast, patients aged $\geq 55$ years $(0.69$ [0.53-0.90]) vs. $<40$ years, SSA migrants (men: 0.45 [0.24-0.84]; women: 0.18 [0.09-0.36]) vs. MSM, those who were overweight $(0.74[0.62-0.89])$ or obese $(0.63[0.42-0.96])$ vs. in normal weight range and those reporting high $(0.75[0.60-0.95])$ vs. low physical activity level were less likely to be regular smokers.

Heavy drinking was more likely to be observed among illegal substance users (1.41 [1.07-1.87]) vs. non-users, past $(2.26[1.60-3.18])$ vs. never smokers, those who were overweight (1.4 [1.08-1.81]) vs. in normal weight range and those with low (1.52 [1.14-2.03]) vs. high future outlook while those aged $40-55$ years $(0.66[0.49-0.87])$ or $\geq 55$ years $(0.62$ $[0.41-0.92])$ vs. $<40$ years, non-African heterosexual women $(0.51[0.33-0.79])$ vs. MSM and those living in a couple with children $(0.52$ [0.28-0.95]) vs. living alone had lower risk of being heavy drinkers, according to the multivariable analysis in table 2.

Low physical activity was more frequent among those with low educational attainment (primary school: 2.41 [1.53-3.80]; middle school: 1.82 [1.19-2.79]) vs. >2-year 
university degree and those reporting disturbance from HIV symptoms (1.9 [1.33-2.71]) vs. those who did not, whereas alcohol intake (heavy drinking: 0.68 [0.46-1.00]; low/moderate drinking: 0.56 [0.43-0.73]) vs. abstinence was inversely associated with low physical activity, according to the multivariable analysis in table 3.

Obesity was more likely to be reported among SSA migrants (men: 2.32 [1.13-4.75]; women: 3.51 [2.05-6.02]) and non-African heterosexuals (men: 1.86 [1.02-3.40]; women: $3.16[1.92-5.21])$ vs. MSM while past smokers $(0.56$ [0.32-0.99]) vs. never smokers and those diagnosed for HIV-infection before 1996 (0.58 [0.37-0.88]) vs. after 2003 were less likely to be obese, according to the multivariable analysis in table 3 .

\section{Sensitivity analysis}

Results from sensitivity analysis on complete cases were consistent despite slight differences in the intensity/significance of associations between some covariates and BMI or physical activity, but this is likely caused by the loss of participants in the complete cases analysis (data not shown).

\section{Discussion}

Our findings indicate that half the HIV-infected population (median age : 47) in France in 2011 presented at least one behavioral cardiovascular risk factor (29.4\% regular smoking, $14.8 \%$ low physical activity, $13.8 \%$ heavy drinking, $8.6 \%$ obesity) and $13.8 \%$ combined several risk factors. Patterns of risk factors were heterogeneous across the various groups of PLWHIV. Major correlates of risk factors presence included socioepidemiological group, social status, other unhealthy behaviors and disturbance from HIV symptoms. 
Consistently with previous research, smoking was particularly frequent among IDU, MSM and non-African heterosexuals [19-21]. As suggested by other studies, alcohol intake was elevated mainly among men and IDU [22], which is concerning especially among the latter considering the high risk of hepatic impairment due to a substantial prevalence of hepatitis C (>85\%) [42]. We found that heavy drinking was characterized by drinking $\geq 6$ drinks/occasion at least monthly rather than high daily intake; therefore, this specific problem must be addressed. Authors of the sole study we found assessing physical activity through the Baecke questionnaire among PLWHIV reported similar overall score [24]. Lack of physical activity among IDU might result from illegal drug use being the focus of care among them, with probably little attention on other health behaviors. The global physical activity score is assessed by the sum of the 3 subscores (work/sports activities/leisure time) and increases when each subscore increases. However, physical activity from work might not be of good quality and rather lead to physical impairments, therefore an elevated global score due to a high subscore of physical activity at work might not provide only health benefits [43]. Frequency of obesity was consistent with previous studies with larger rates among SSA migrants [25, 26] and non-African heterosexuals, especially women [17].

Our findings partly support the assumption that unhealthy behaviors often occur in combination in PLWHIV $[21,27,28]$, which is concerning in this population with high cardiovascular risk [7]. In fact, levels of co-occurrence of risk factors (essentially due to tobacco smoking) were very variable across the groups of PLWHIV. Except among IDU and MSM, risk factors were mainly found in isolation in the other groups. Three principal patterns of combination of risk factors emerged: 1) elevated exposure to smoking/alcohol and high co-occurrence of smoking/alcohol/low physical exercise (IDU, MSM), 2) exposure to one of the four risk factors and moderate co-occurrence (non-African heterosexuals, SSA migrant men), and 3) exposure mainly to obesity/low physical activity and low co-occurrence (SSA 
migrant women). Our study stresses the need for comprehensive and multidisciplinary interventions to promote healthier behaviors, focusing not only on tobacco smoking but also on lifestyle in general, accounting for the heterogeneity of profiles and needs among the groups (e.g.: sports/thinness not being part of SSA migrants' culture, content of programs must be adjusted [44]).

Information on determinants of exposure to those risk factors contributes to better target those who need lifestyle modification and guide future preventive interventions among PLWHIV. We found socio-economic inequalities regarding tobacco and alcohol consumption as reported in previous research [20, 21, 44, 45]. Measures to reduce inequalities are not always efficient among PLWHIV [46] hence actions toward the less educated must be strengthened to support positive changes despite unfavorable context. Living with a partner/children seemed protective against alcohol intake, highlighting the role of social support and environment $[44,45,47]$. Yet, we found no association with number of friends/relatives accounting for social network and support. Furthermore, recent diagnosis was a correlate of obesity [25] probably as a consequence of the major changes in the HIV epidemic, which has become a less fatal and damaging disease with cART advent. Other major result of this study was that unhealthy behaviors were closely associated [21, 45], which is alarming considering that it might be harder to engage in better lifestyle when experiencing several risk factors. While the association between alcohol intake and tobacco smoking is well-known, other combinations of risk factors have been rarely investigated. For example, we found that smokers often lacked physical activity or that overweight was associated with heavy drinking. The association between alcohol abstinence and low physical activity might reflect poorer health conditions among abstinent [48] and thus lower ability to exercise. Disturbance from HIV symptoms may also reflect physical impairments, increasing the risk of smoking (as a coping mechanism to reduce pain [45]) and reducing 
capacity to exercise [47] whereas it has been shown that tobacco cessation and physical activity can reduce symptoms and increase mental/physical quality of life in a chronic disease context $[23,32,49]$. Besides, the association found between present-time orientation trait and smoking/drinking-commonly observed in the general population- has been rarely investigated and might be exacerbated among PLWHIV because of their belief that they would not live long enough to experience consequences of such behaviors [45]. It is thus necessary to better promote the benefits of alcohol/smoking cessation and exercise in the context of HIV-infection [44]. In addition, interventions to improve physical activity must be progressive and adjusted to PLWHIV's medical conditions [50] and all interventions must enhance motivation which is key to engagement in behavior modification [17, 44, 47, 49].

Our study is one of the first to assess frequency, co-occurrence, and determinants of the major behavioral cardiovascular risk factors across the various groups of HIV-infected people, using large national representative data about PLWHIV. However, limitations to this study must be acknowledged. First, data being self-reported (except BMI), frequencies might have been underestimated, but the use of standardized and validated questionnaires in this study has probably limited this bias. In addition, we did not collect information on nutrition also known to influence cardiovascular risk. Then, it would have been interesting to investigate how HIV diagnosis influenced the considered behaviors and the delay for behavioral change after HIV diagnosis, since we can assume HIV diagnosis and medical follow-up may induce changes in unhealthy behaviors (and the longer the time since HIV diagnosis, the more time patients will have to modify their behaviors). However, our crosssectional data did not allow us to conduct such analyses. Moreover, since risk factors are known to increase mortality of HIV-infected people in the CART era [51], we cannot ignore a potential survival bias among those with the longest time since HIV diagnosis. Nevertheless, such survival bias must have a minimal impact on our results, since until the 
end of the 90s, the mortality caused by cardiovascular factors was substantially lower than the mortality caused by HIV-infection. We are also aware that multiple imputations have limitations, but sensitivity analyses on complete cases were consistent with results from the imputed dataset and this method is probably better than other/no treatment of missing data [39]. We cannot guarantee that the "Missing at Random" (MAR) hypothesis is valid regarding multiple imputation of physical activity items, since non-response for this outcome was associated with its value. However, statistical significance was borderline ( $p$-value $=0.040$ ) and we disposed of many "auxiliary variables" (reducing the risk of prediction bias that could result from a potential breach of the MAR hypothesis). Moreover, considering the very high rate of missing value on the global physical activity score $(47.5 \%)$ it was certainly better to perform multiple imputation in this case. Finally, our data are representative of PLWHIV attending French hospitals rather than the whole HIV-infected population. However, in France since an annual hospital full check-up is requested for all HIV-infected people in care [9], those exclusively followed outside the hospital might represent a small proportion of the whole PLHIV population.

In conclusion, this study provides evidence for overall elevated exposure to behavioral cardiovascular risk factors but most importantly, it shows a huge diversity in profiles across the various groups of PLWHIV. Co-occurrence of risk factors was mainly observed among people ever infected through drug injection and, to a lesser extent among MSM. Tobacco smoking was the most predominant risk factor but all of them were present and must be addressed. Our findings overall suggest that PLWHIV might not be ready to engage in healthier lifestyle because they presented major barriers to change (clusters of risk factors, present-oriented attitude, disturbance from HIV symptoms). Intervention programs must be comprehensive, accompanied by better information on benefits of lifestyle 
improvement, tailored to the specific needs of the various HIV-infected groups, and supportive, for sustained efficiency over time. Health education and preventive care towards PLWHIV could be conducted through therapeutic education programs or general practitioners. 


\section{Acknowledgements}

The authors are deeply grateful to the people living with HIV who agreed to participate in the ANRS-Vespa2 study and to all the investigators at the participating hospitals.

They also thank Yann Le Strat (InVS, Saint-Maurice), Lise Cuzin (Hôpital Purpan, Toulouse) and Laurence Meyer (INSERM UMR-S 1018, Le Kremlin Bicêtre) for their methodological support, and the community-based organisations AIDES and Act-Up Paris for their ground support for implementing the ANRS-Vespa2 study.

The authors also thank Vanina Bousquet (InVS, Saint-Maurice) for her advice on the statistical methodology to handle missing data for the purpose of this study.

The Vespa2 study was sponsored and funded by the ANRS (Agence Nationale de Recherche sur le Sida et les Hépatites Virales), Paris, France. 
Conflicts of Interest:

None 


\section{References}

1. The Antiretroviral Therapy Cohort Collaboration. Life expectancy of individuals on combination antiretroviral therapy in high-income countries: a collaborative analysis of 14 cohort studies. Lancet. 2008;372(9635):293-9.

2. Morlat P, Roussillon C, Henard S, Salmon D, Bonnet F, Cacoub P, et al. Causes of death among HIV-infected patients in France in 2010 (national survey): trends since 2000. AIDS. 2014;28(8):1181-91 10.097/QAD.0000000000000222.

3. Hasse B, Ledergerber B, Furrer H, Battegay M, Hirschel B, Cavassini M, et al. Morbidity and aging in HIV-infected persons: the Swiss HIV cohort study. Clin Infect Dis. 2011;53(11):1130-9.

4. Hemkens LG, Bucher HC. HIV infection and cardiovascular disease. Eur Heart J. 2014;9:9.

5. Wang T, Yi R, Green LA, Chelvanambi S, Seimetz M, Clauss M. Increased cardiovascular disease risk in the HIV-positive population on ART: potential role of HIV-Nef and Tat. Cardiovasc Pathol. 2015 Sep-Oct;24(5):279-82.

6. Friis-Moller N, Reiss P, Sabin CA, Weber R, Monforte A, El-Sadr W, et al. Class of antiretroviral drugs and the risk of myocardial infarction. N Engl J Med. 2007;356(17):1723-35.

7. Shahmanesh M, Schultze A, Burns F, Kirk O, Lundgren J, Mussini C, et al. The cardiovascular risk management for people living with HIV in Europe: how well are we doing? AIDS. 2016 Jul 22.

8. Gutierrez J, Elkind MS, Marshall RS. Cardiovascular profile and events of US adults 20-49 years with HIV: Results from the NHANES 1999-2008. AIDS Care. 2013;21:21.

9. Morlat $\mathrm{P}$, ed. Prise en charge médicale des personnes vivant avec le VIH. Recommandations du groupe d'experts. Rapport 2013. Paris: La documentation française2013.

10. Hasse B, Tarr PE, Marques-Vidal P, Waeber G, Preisig M, Mooser V, et al. Strong Impact of Smoking on Multimorbidity and Cardiovascular Risk Among Human Immunodeficiency VirusInfected Individuals in Comparison With the General Population. Open forum infectious diseases. 2015 Sep;2(3):ofv108.

11. Rasmussen LD, Helleberg M, May M, Afzal S, Kronborg G, Larsen CS, et al. Myocardial infarction among Danish HIV-infected individuals: Population attributable fractions associated with smoking. Clin Infect Dis. 2015 Jan 16.

12. Kelly SG, Plankey M, Post WS, Li X, Stall R, Jacobson LP, et al. Associations between Tobacco, Alcohol, and Drug Use with Coronary Artery Plaque among HIV-Infected and Uninfected Men in the Multicenter AIDS Cohort Study. PLoS One. 2016;11(1):e0147822.

13. Freiberg MS, McGinnis KA, Kraemer K, Samet JH, Conigliaro J, Curtis Ellison R, et al. The association between alcohol consumption and prevalent cardiovascular diseases among HIVinfected and HIV-uninfected men. J Acquir Immune Defic Syndr. 2010 Feb;53(2):247-53.

14. Hand GA, Lyerly GW, Jaggers JR, Dudgeon WD. Impact of Aerobic and Resistance Exercise on the Health of HIV-Infected Persons. American journal of lifestyle medicine. 2009 Nov 1;3(6):48999.

15. Dirajlal-Fargo S, Webel AR, Longenecker CT, Kinley B, Labbato D, Sattar A, et al. The effect of physical activity on cardiometabolic health and inflammation in treated HIV infection. Antivir Ther. 2015 Oct 12.

16. Koethe JR, Grome H, Jenkins CA, Kalams SA, Sterling TR. The metabolic and cardiovascular consequences of obesity in persons with HIV on long-term antiretroviral therapy. AIDS. 2016 Jan 2;30(1):83-91. 
17. Keithley JK, Duloy AM, Swanson B, Zeller JM. HIV infection and obesity: a review of the evidence. J Assoc Nurses AIDS Care. 2009 Jul-Aug;20(4):260-74.

18. Hasse B, Iff M, Ledergerber B, Calmy A, Schmid P, Hauser C, et al. Obesity Trends and Body Mass Index Changes After Starting Antiretroviral Treatment: The Swiss HIV Cohort Study. Open forum infectious diseases. 2014 Sep;1(2):ofu040.

19. Tron L, Lert F, Spire B, Dray-Spira R and the ANRS-Vespa2 study group. Tobacco smoking in HIV-infected versus general population in France: heterogeneity across the various groups of people living with HIV. PLoS One. 2014;9(9):e107451.

20. Mdodo R, Frazier EL, Dube SR, Mattson CL, Sutton MY, Brooks JT, et al. Cigarette Smoking Prevalence Among Adults With HIV Compared With the General Adult Population in the United States: Cross-sectional Surveys. Ann Intern Med. 2015 Mar 3;162(5):335-44.

21. O'Cleirigh C, Valentine SE, Pinkston M, Herman D, Bedoya CA, Gordon JR, et al. The unique challenges facing HIV-positive patients who smoke cigarettes: HIV viremia, ART adherence, engagement in HIV care, and concurrent substance use. AIDS Behav. 2015 Jan;19(1):178-85.

22. Marshall BD, Operario D, Bryant KJ, Cook RL, Edelman EJ, Gaither JR, et al. Drinking trajectories among HIV-infected men who have sex with men: a cohort study of United States veterans. Drug Alcohol Depend. 2015 Mar 1;148:69-76.

23. Fazeli PL, Marquine MJ, Dufour C, Henry BL, Montoya J, Gouaux B, et al. Physical Activity is Associated with Better Neurocognitive and Everyday Functioning Among Older Adults with HIV Disease. AIDS Behav. 2015 Aug;19(8):1470-7.

24. Florindo AA, Latorre Mdo R, Santos EC, Negrao CE, Azevedo LF, Segurado AA. Validity and reliability of the Baecke questionnaire for the evaluation of habitual physical activity among people living with HIV/AIDS. Cad Saude Publica. 2006 Mar;22(3):535-41.

25. Crum-Cianflone N, Roediger MP, Eberly L, Headd M, Marconi V, Ganesan A, et al. Increasing rates of obesity among HIV-infected persons during the HIV epidemic. PLoS One. 2010;5(4):e10106. 26. Ilozue C, Howe B, Shaw S, Haigh K, Hussey J, Price DA, et al. Obesity in the HIV-infected population in Northeast England: a particular issue in Black-African women. International journal of STD \& AIDS. 2016 May 4.

27. Loef $\mathrm{M}$, Walach $\mathrm{H}$. The combined effects of healthy lifestyle behaviors on all cause mortality: a systematic review and meta-analysis. Prev Med. 2012 Sep;55(3):163-70.

28. Fonquernie L, Clozel S, Vincensini JP, Boccara F, Rousselle B, Pitard C, et al. [Early diagnosis and prevention of comorbidities among HIV-infected patients: the Orchestra Saint-Antoine Program]. Medecine et maladies infectieuses. 2007 Dec;37 Suppl 3:S229-36.

29. WHO. Prevention of cardiovascular disease : guidelines for assessment and management of total cardiovascular risk, 2007.

30. Brown JL, DeMartini KS, Sales JM, Swartzendruber AL, DiClemente RJ. Interventions to reduce alcohol use among HIV-infected individuals: a review and critique of the literature. Curr HIV/AIDS Rep. 2013 Dec;10(4):356-70.

31. Pool ER, Dogar O, Lindsay RP, Weatherburn P, Siddiqi K. Interventions for tobacco use cessation in people living with HIV and AIDS. The Cochrane database of systematic reviews. 2016;6:CD011120.

32. Botros D, Somarriba G, Neri D, Miller TL. Interventions to address chronic disease and HIV: strategies to promote exercise and nutrition among HIV-infected individuals. Curr HIV/AIDS Rep. 2012 Dec;9(4):351-63.

33. Dray-Spira R, Spire B, Lert F, and the ANRS-Vespa2 study group. General Method of the ANRS-VESPA2 Study. Bull Epidemiol Hebd. 2013;26-27:321-24. 
34. Vol S, Bedouet M, Gusto G, Leglu C, Beslin E, Decou P, et al. Evaluating physical activity: the AQAP questionnaire and its interpretation software. Ann Phys Rehabil Med. 2011 Nov;54(8):47895.

35. Baecke JA, Burema J, Frijters JE. A short questionnaire for the measurement of habitual physical activity in epidemiological studies. Am J Clin Nutr. 1982 Nov;36(5):936-42.

36. WHO. Obesity: preventing and managing the global epidemic. Report of a WHO Consultation. WHO Technical Report Series 8942000.

37. Peretti-Watel P, L'Haridon O, Seror V. Time preferences, socioeconomic status and smokers' behaviour, attitudes and risk awareness. Eur J Public Health. 2013 Oct;23(5):783-8.

38. Justice AC, Holmes W, Gifford AL, Rabeneck L, Zackin R, Sinclair G, et al. Development and validation of a self-completed HIV symptom index. J Clin Epidemiol. 2001 Dec;54 Suppl 1:S77-90.

39. Sterne JA, White IR, Carlin JB, Spratt M, Royston P, Kenward MG, et al. Multiple imputation for missing data in epidemiological and clinical research: potential and pitfalls. BMJ. 2009;338:b2393.

40. Rubin DB. Multiple Imputation for Nonresponse in Surveys. New York: Wiley; 1987.

41. White IR, Royston P, Wood AM. Multiple imputation using chained equations: Issues and guidance for practice. Statistics in medicine. $2011 \mathrm{Feb}$ 20;30(4):377-99.

42. Dray-Spira R, Wilson-d'Almeida K, Aubrière C, Marcellin F, Spire B, Lert F, et al. Health status of people living with HIV followed at hospital in metropolitan France in 2011 and characteristics of those recently diagnosed. Results of the ANRS-Vespa2 study. Bull Epidemiol Hebd. 2013;26-27:28592.

43. Ruzic L, Heimer S, Misigoj-Durakovic M, Matkovic BR. Increased occupational physical activity does not improve physical fitness. Occup Environ Med. 2003 Dec;60(12):983-5.

44. Capili B, Anastasi JK, Chang M, Ogedegbe O. Barriers and facilitators to engagement in lifestyle interventions among individuals with HIV. J Assoc Nurses AIDS Care. 2014 SepOct;25(5):450-7.

45. Rahmanian S, Wewers ME, Koletar S, Reynolds N, Ferketich A, Diaz P. Cigarette smoking in the HIV-infected population. Proc Am Thorac Soc. 2011;8(3):313-9.

46. Peretti-Watel P, Villes V, Duval X, Collin F, Reynes J, Sobel A, et al. How do HIV-infected smokers react to cigarette price increases? Evidence from the APROCO-COPILOTE-ANRS CO8 Cohort. Curr HIV Res. 2009;7(4):462-7.

47. Montoya JL, Wing D, Knight A, Moore DJ, Henry BL. Development of an mHealth Intervention (iSTEP) to Promote Physical Activity among People Living with HIV. Journal of the International Association of Providers of AIDS Care. 2015 Nov-Dec;14(6):471-5.

48. Stockwell T, Zhao J, Panwar S, Roemer A, Naimi T, Chikritzhs T. Do "Moderate" Drinkers Have Reduced Mortality Risk? A Systematic Review and Meta-Analysis of Alcohol Consumption and AllCause Mortality. Journal of studies on alcohol and drugs. 2016 Mar;77(2):185-98.

49. Kariuki W, Manuel JI, Kariuki N, Tuchman E, O'Neal J, Lalanne GA. HIV and smoking: associated risks and prevention strategies. HIV AIDS (Auckl). 2016;8:17-36.

50. Dolan SE, Frontera W, Librizzi J, Ljungquist K, Juan S, Dorman R, et al. Effects of a supervised home-based aerobic and progressive resistance training regimen in women infected with human immunodeficiency virus: a randomized trial. Arch Intern Med. 2006 Jun 12;166(11):1225-31.

51. Obel N, Omland LH, Kronborg G, et al. Impact of non-HIV and HIV risk factors on survival in HIV-infected patients on HAART: a population-based nationwide cohort study. PLoS One. 2011;6(7):25. 
Table 1. Characteristics of the studied sample (Weighted \%), ANRS-Vespa2 study, France, 2011

MSM: men who have sex with men, IDU: intravenous drug use, SSA: sub-Saharan African

\begin{tabular}{|c|c|c|c|c|c|c|c|c|}
\hline & $\begin{array}{c}\text { Total } \\
(\mathrm{N}=2,537)\end{array}$ & $\begin{array}{c}\text { MSM } \\
(\mathrm{N}=1,201)\end{array}$ & $\begin{array}{l}\text { IDU men } \\
(\mathrm{N}=162)\end{array}$ & $\begin{array}{l}\text { IDU women } \\
\qquad(\mathrm{N}=112)\end{array}$ & $\begin{array}{c}\text { SSA migrant } \\
\text { men } \\
(N=120)\end{array}$ & $\begin{array}{l}\text { SSA migrant } \\
\text { women } \\
(N=309)\end{array}$ & $\begin{array}{l}\text { Non-IDU non- } \\
\text { African men } \\
(\mathrm{N}=302)\end{array}$ & $\begin{array}{c}\text { Non-IDU non- } \\
\text { African women } \\
\quad(\mathrm{N}=331)\end{array}$ \\
\hline \multicolumn{9}{|l|}{ Age } \\
\hline $18-40$ years & 22.7 & 18.9 & 1.0 & 14.6 & 29.1 & 54.3 & 11.4 & 17.7 \\
\hline $40-55$ years & 54.3 & 55.1 & 87.5 & 75.0 & 53.9 & 37.6 & 43.2 & 58.4 \\
\hline $55-88$ years & 23.0 & 25.9 & 11.5 & 10.4 & 17.0 & 8.1 & 45.43 & 23.9 \\
\hline \multicolumn{9}{|l|}{ Socio-epidemiological group } \\
\hline MSM & 39.4 & & & & & & & \\
\hline IDU men & 6.6 & & & & & & & \\
\hline IDU women & 4.4 & & & & & & & \\
\hline SSA migrant men & 7.9 & & & & & & & \\
\hline SSA migrant women & 15.6 & & & & & & & \\
\hline Non-IDU non-African men & 12.7 & & & & & & & \\
\hline Non-IDU non-African women & 13.4 & & & & & & & \\
\hline \multicolumn{9}{|l|}{ Household composition } \\
\hline Single without children & 39.4 & 54.6 & 38.9 & 33.5 & 31.6 & 20.2 & 32.6 & 30.4 \\
\hline Single with children & 5.0 & 0.0 & 2.5 & 8.2 & 0.7 & 16.5 & 1.1 & 13.0 \\
\hline Couple with children & 9.9 & 1.7 & 11.1 & 8.1 & 27.0 & 20.1 & 11.6 & 10.2 \\
\hline Couple without children & 20.0 & 26.3 & 15.2 & 22.2 & 10.8 & 6.3 & 26.3 & 18.6 \\
\hline Other situation & 25.7 & 17.5 & 32.3 & 28.1 & 30.0 & 36.9 & 28.5 & 27.8 \\
\hline \multicolumn{9}{|l|}{ Educational level } \\
\hline Primary school & 16.4 & 8.7 & 22.8 & 29.2 & 18.8 & 25.2 & 17.9 & 18.1 \\
\hline
\end{tabular}


Figure 1. Frequency of each behavioral cardiovascular risk factor among people living with HIV, overall and by group, ANRS-Vespa2 study, France, 2011

MSM: men who have sex with men, IDU: intravenous drug use, SSA: sub-Saharan African

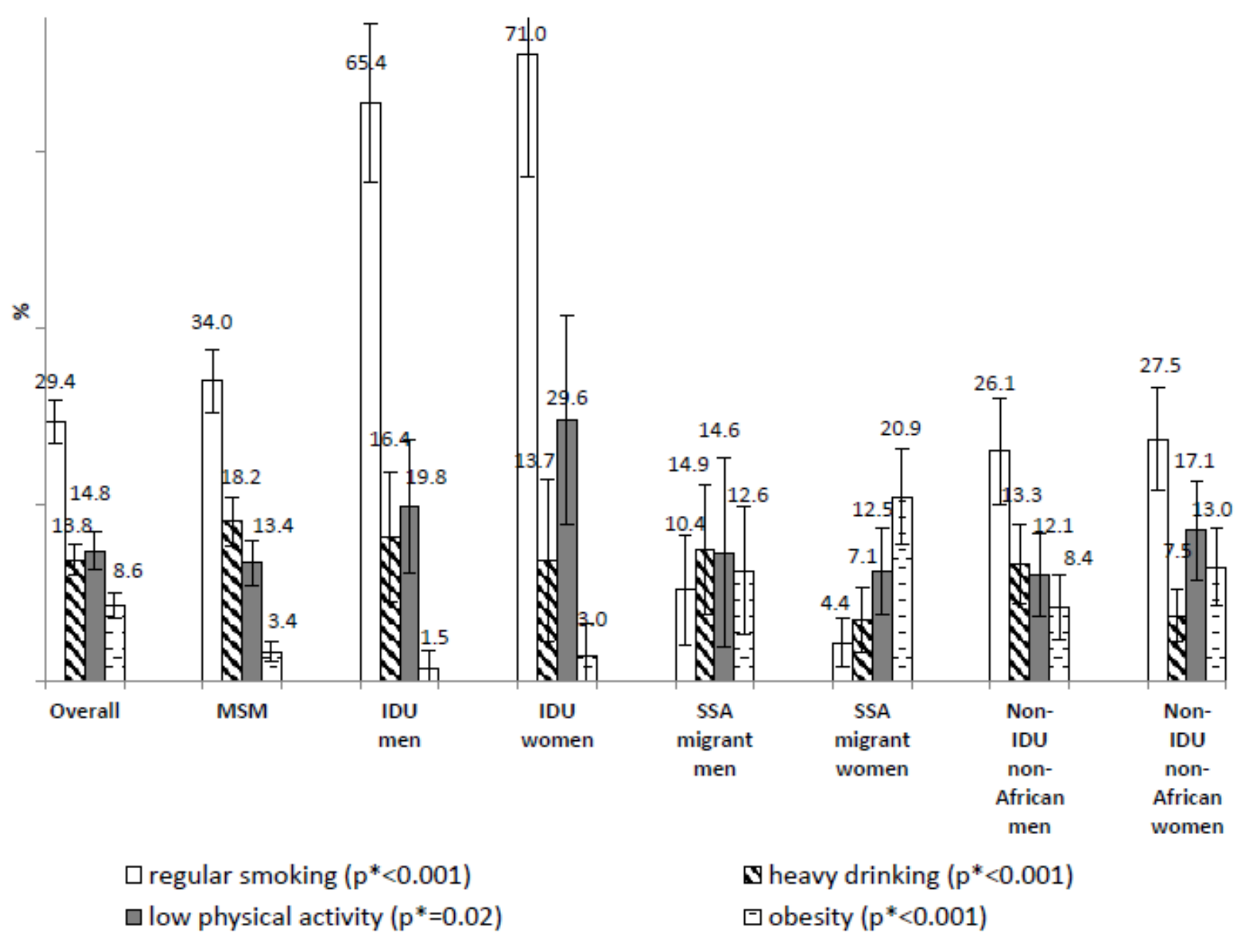

*P-value of the statistical test of difference in risk factor level across the groups 
Figure 2. Behavioral cardiovascular risk factors profiles among people living with HIV, overall and by group, ANRS-Vespa2 study, France, 2011

MSM: men who have sex with men, IDU: intravenous drug use, SSA: sub-Saharan African

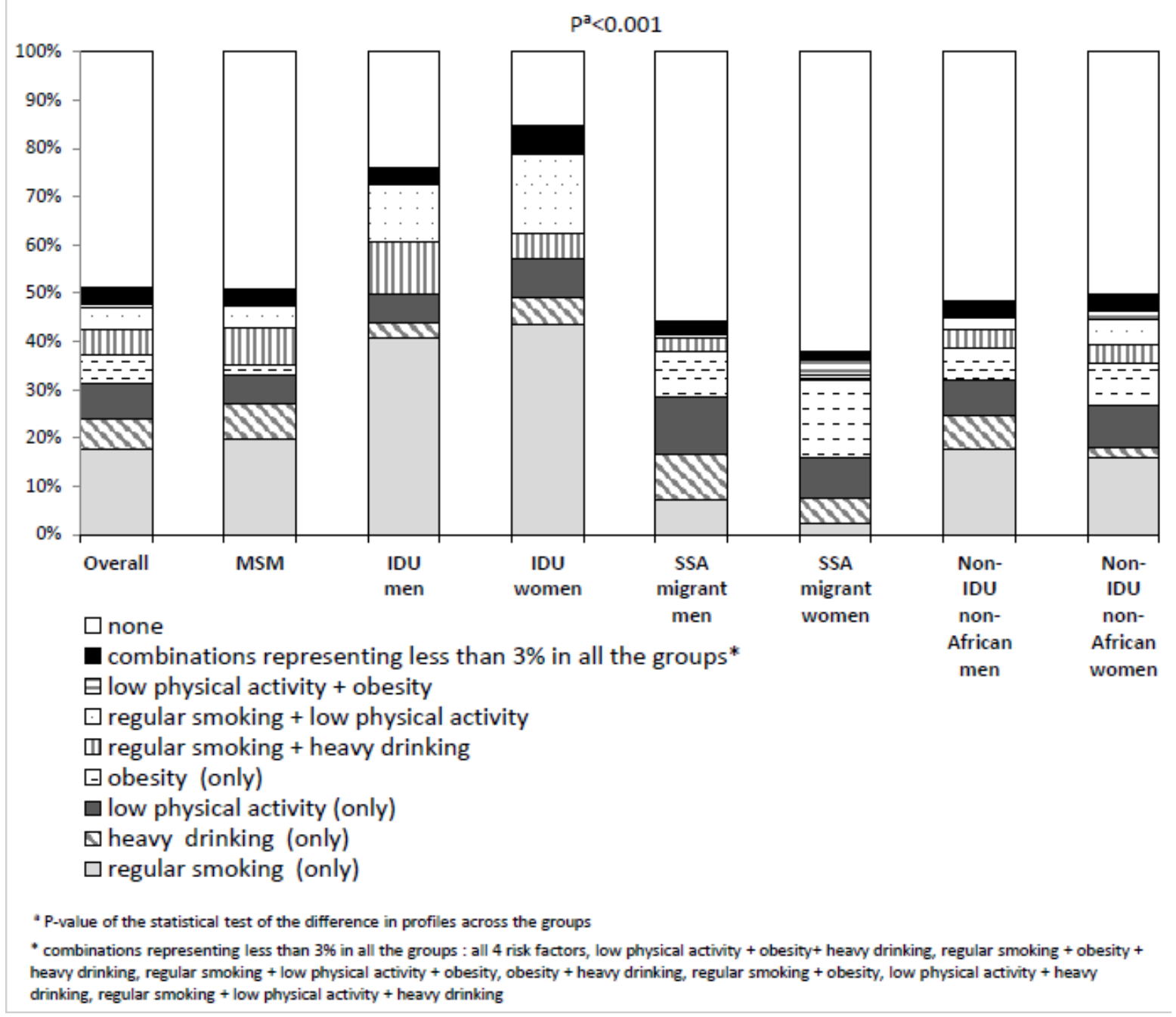


Table 2. Factors associated with regular smoking and heavy drinking in HIV-infected people, ANRS-

Vespa2 study, France, 2011

aPRR: adjusted prevalence rate ratio, 95\% Cl: 95\% Confidence Interval, MSM: men who have sex with men, IDU: intravenous drug use, SSA: sub-

Saharan African

\begin{tabular}{|c|c|c|c|c|c|c|c|c|c|c|}
\hline & \multicolumn{5}{|c|}{ Regular smoking } & \multicolumn{5}{|c|}{ Heavy drinking } \\
\hline & \multicolumn{2}{|c|}{$\begin{array}{c}\text { Univariable } \\
\text { analysis }\end{array}$} & \multicolumn{3}{|c|}{ Multivariable analysis } & \multicolumn{2}{|c|}{$\begin{array}{c}\text { Univariable } \\
\text { analysis }\end{array}$} & \multicolumn{3}{|c|}{ Multivariable analysis } \\
\hline & $\%$ & $p$ & aPRR & $95 \% \mathrm{Cl}$ & $p$ & $\%$ & $\mathrm{p}$ & aPRR & $95 \% \mathrm{Cl}$ & $p$ \\
\hline \multicolumn{11}{|l|}{ Age } \\
\hline $18-40$ years & 24.2 & $<0.001$ & 1 & . & . & 16.5 & 0.236 & 1 & . & . \\
\hline $40-55$ years & 34.9 & & 0.99 & {$[0.81 ; 1.20]$} & 0.916 & 13.5 & & 0.66 & {$[0.49 ; 0.87]$} & 0.004 \\
\hline $55-88$ years & 21.4 & & 0.69 & {$[0.53 ; 0.90]$} & 0.006 & 11.9 & & 0.62 & {$[0.41 ; 0.92]$} & 0.020 \\
\hline $\begin{array}{l}\text { Socio-epidemiological } \\
\text { group }\end{array}$ & & & & & & & & & & \\
\hline MSM & 34.0 & $<0.001$ & 1 & . & . & 18.2 & $<0.001$ & 1 & . & . \\
\hline IDU men & 65.4 & & 1.24 & {$[1.02 ; 1.51]$} & 0.033 & 16.4 & & 0.81 & {$[0.50 ; 1.33]$} & 0.398 \\
\hline IDU women & 71.0 & & 1.28 & {$[1.02 ; 1.60]$} & 0.030 & 13.7 & & 0.62 & {$[0.34 ; 1.13]$} & 0.116 \\
\hline SSA migrant men & 10.4 & & 0.45 & {$[0.24 ; 0.84]$} & 0.013 & 14.9 & & 1.36 & {$[0.79 ; 2.34]$} & 0.265 \\
\hline SSA migrant women & 4.4 & & 0.18 & {$[0.09 ; 0.36]$} & $<0.001$ & 7.1 & & 0.71 & {$[0.38 ; 1.31]$} & 0.269 \\
\hline Non-IDU non-African men & 26.1 & & 0.96 & {$[0.76 ; 1.22]$} & 0.743 & 13.3 & & 0.89 & {$[0.63 ; 1.27]$} & 0.518 \\
\hline Non-IDU non-African & 27.5 & & 0.87 & {$[0.69 ; 1.11]$} & 0.269 & 7.5 & & 0.51 & {$[0.33 ; 0.79]$} & 0.003 \\
\hline \multicolumn{11}{|l|}{ women } \\
\hline \multicolumn{11}{|l|}{ Household composition } \\
\hline Single without children & 33.6 & 0.011 & 1 & . & . & 16.5 & 0.006 & 1 & . & . \\
\hline Single with children & 24.2 & & 1.02 & {$[0.73 ; 1.43]$} & 0.897 & 11.4 & & 0.95 & {$[0.48 ; 1.88]$} & 0.886 \\
\hline Couple with children & 22.5 & & 1.17 & {$[0.91 ; 1.50]$} & 0.216 & 7.0 & & 0.52 & {$[0.28 ; 0.95]$} & 0.034 \\
\hline Couple without children & 30.2 & & 0.92 & {$[0.78 ; 1.08]$} & 0.319 & 16.3 & & 0.94 & {$[0.71 ; 1.24]$} & 0.649 \\
\hline Other situation & 25.9 & & 0.93 & {$[0.78 ; 1.10]$} & 0.372 & 10.9 & & 0.76 & {$[0.54 ; 1.07]$} & 0.110 \\
\hline \multicolumn{11}{|l|}{ Educational level } \\
\hline Primary school & 26.2 & 0.008 & 1.02 & {$[0.79 ; 1.31]$} & 0.866 & 13.6 & 0.895 & & & \\
\hline Middle school & 33.7 & & 1.31 & {$[1.07 ; 1.60]$} & 0.008 & 13.0 & & & & \\
\hline High school & 25.6 & & 1.13 & {$[0.89 ; 1.43]$} & 0.328 & 14.3 & & & & \\
\hline 2 years university degree & 34.6 & & 1.27 & {$[1.00 ; 1.61]$} & 0.050 & 15.8 & & & & \\
\hline$>2$ years university degree & 25.0 & & 1 & . & . & 14.1 & & & & \\
\hline \multicolumn{11}{|l|}{ Number of relatives or } \\
\hline \multicolumn{11}{|l|}{ friends } \\
\hline $0-5$ & 28.7 & 0.149 & 1 & . & . & 12.2 & 0.002 & 1 & . & . \\
\hline $6-7$ & 26.9 & & 1.08 & {$[0.89 ; 1.30]$} & 0.448 & 10.3 & & 0.91 & {$[0.63 ; 1.30]$} & 0.588 \\
\hline
\end{tabular}




\begin{tabular}{|c|c|c|c|c|c|c|c|c|c|c|}
\hline $8-10$ & 28.7 & & 1.05 & {$[0.86 ; 1.27]$} & 0.650 & 14.2 & & 1.10 & {$[0.78 ; 1.55]$} & 0.592 \\
\hline$>11$ & 33.7 & & 1.04 & {$[0.86 ; 1.26]$} & 0.677 & 19.0 & & 1.35 & {$[0.96 ; 1.91]$} & 0.084 \\
\hline \multicolumn{11}{|c|}{ Illegal substance use in } \\
\hline \multicolumn{11}{|l|}{ the month } \\
\hline No & 21.4 & $<0.001$ & 1 & . & . & 12.0 & $<0.001$ & 1 & . & . \\
\hline Yes & 76.8 & & 2.12 & {$[1.81 ; 2.49]$} & $<0.001$ & 24.5 & & 1.41 & {$[1.07 ; 1.87]$} & 0.016 \\
\hline \multicolumn{11}{|l|}{ Tobacco consumption } \\
\hline Non smokers & & & & & & 8.2 & $<0.001$ & 1 & . & . \\
\hline Past smokers & & & & & & 21.3 & & 2.26 & {$[1.60 ; 3.18]$} & $<0.001$ \\
\hline Current smokers & & & & & & 12.1 & & 1.45 & {$[0.94 ; 2.23]$} & 0.090 \\
\hline \multicolumn{11}{|l|}{ Alcohol consumption } \\
\hline Abstinence & 27.2 & $<0.001$ & 1 & . & . & & & & & \\
\hline Low/moderate drinking & 26.2 & & 0.97 & {$[0.83 ; 1.13]$} & 0.684 & & & & & \\
\hline Heavy drinking & 47.5 & & 1.36 & {$[1.13 ; 1.64]$} & 0.002 & & & & & \\
\hline \multicolumn{11}{|l|}{ Body mass index } \\
\hline Underweight & 51.2 & $<0.001$ & 1.01 & {$[0.83 ; 1.24]$} & 0.894 & 9.0 & 0.129 & 0.6 & {$[0.34 ; 1.07]$} & 0.083 \\
\hline Normal weight & 34.8 & & 1 & . & . & 14.2 & & 1 & . & . \\
\hline Overweight & 18.5 & & 0.74 & {$[0.62 ; 0.89]$} & 0.002 & 15.6 & & 1.40 & {$[1.08 ; 1.81]$} & 0.013 \\
\hline Obesity & 12.0 & & 0.63 & {$[0.42 ; 0.96]$} & 0.031 & 9.0 & & 1.06 & {$[0.63 ; 1.79]$} & 0.824 \\
\hline \multicolumn{11}{|c|}{ Level of physical activity } \\
\hline Low & 38.4 & 0.004 & 1 & . & . & 13.2 & 0.892 & & & \\
\hline Medium & 28.5 & & 0.86 & {$[0.74 ; 1.01]$} & 0.063 & 14.1 & & & & \\
\hline High & 25.6 & & 0.75 & {$[0.60 ; 0.95]$} & 0.016 & 13.3 & & & & \\
\hline \multicolumn{11}{|l|}{ Future outlook } \\
\hline Low & 41.8 & $<0.001$ & 1.57 & {$[1.32 ; 1.88]$} & $<0.001$ & 19.4 & $<0.001$ & 1.52 & {$[1.14 ; 2.03]$} & 0.005 \\
\hline Neutral & 32.2 & & 1.46 & {$[1.22 ; 1.75]$} & $<0.001$ & 12.9 & & 1.14 & {$[0.84 ; 1.54]$} & 0.404 \\
\hline High & 17.1 & & 1 & . & . & 10.3 & & 1 & . & . \\
\hline \multicolumn{11}{|l|}{ Period of HIV diagnosis } \\
\hline Before 1996 & 38.0 & $<0.001$ & 1.02 & {$[0.85 ; 1.22]$} & 0.832 & 14.4 & 0.835 & & & \\
\hline 1996-2003 & 25.5 & & 1.01 & {$[0.81 ; 1.25]$} & 0.926 & 13.5 & & & & \\
\hline After 2003 & 22.2 & & 1 & . & . & 13.4 & & & & \\
\hline \multicolumn{11}{|l|}{ Disturbance from HIV } \\
\hline \multicolumn{11}{|l|}{ symptoms } \\
\hline No & 23.3 & $<0.001$ & 1 & . & . & 14.3 & 0.697 & & & \\
\hline Yes & 32.4 & & 1.19 & {$[1.02 ; 1.39]$} & 0.027 & 13.6 & & & & \\
\hline
\end{tabular}

aPRR: adjusted prevalence rate ratio, 95\%Cl: 95\% Confidence Interval, MSM: men who have sex with men, IDU: intravenous drug use, SSA: subSaharan African 
Table 3. Factors associated with low physical activity and obesity in HIV-infected people, ANRS-Vespa2 study, France, 2011

aPRR: adjusted prevalence rate ratio, $95 \% \mathrm{Cl}$ : $95 \%$ Confidence Interval, MSM: men who have sex with men, IDU: intravenous drug use, SSA: sub-

Saharan African

\begin{tabular}{|c|c|c|c|c|c|c|c|c|c|c|}
\hline & \multicolumn{5}{|c|}{ Low physical activity } & \multicolumn{5}{|c|}{ Obesity } \\
\hline & \multicolumn{2}{|c|}{$\begin{array}{c}\text { Univariable } \\
\text { analysis }\end{array}$} & \multicolumn{3}{|c|}{ Multivariable analysis } & \multicolumn{2}{|c|}{$\begin{array}{c}\text { Univariable } \\
\text { analysis }\end{array}$} & \multicolumn{3}{|c|}{ Multivariable analysis } \\
\hline & $\%$ & $p$ & aPRR & $95 \% \mathrm{Cl}$ & $p$ & $\%$ & $p$ & aPRR & $95 \% \mathrm{Cl}$ & $p$ \\
\hline \multicolumn{11}{|l|}{ Age } \\
\hline $18-40$ years & 14.6 & 0.118 & 1 & . & . & 9.8 & 0.668 & 1 & . & . \\
\hline $40-55$ years & 13.7 & & 0.81 & {$[0.55 ; 1.19]$} & 0.275 & 8.1 & & 1.50 & {$[0.95 ; 2.37]$} & 0.081 \\
\hline $55-88$ years & 17.8 & & 1.23 & {$[0.82 ; 1.85]$} & 0.310 & 8.7 & & 1.65 & {$[0.94 ; 2.88]$} & 0.078 \\
\hline $\begin{array}{l}\text { Socio-epidemiological } \\
\text { group }\end{array}$ & & & & & & & & & & \\
\hline MSM & 13.4 & 0.020 & 1 & . & . & 3.4 & $<0.001$ & 1 & . & . \\
\hline IDU men & 19.8 & & 1.01 & {$[0.63 ; 1.62]$} & 0.978 & 1.5 & & 0.50 & {$[0.11 ; 2.23]$} & 0.360 \\
\hline IDU women & 29.6 & & 1.17 & {$[0.74 ; 1.87]$} & 0.492 & 3.0 & & 1.10 & {$[0.31 ; 3.85]$} & 0.883 \\
\hline SSA migrant men & 14.6 & & 0.98 & {$[0.50 ; 1.92]$} & 0.954 & 12.6 & & 2.32 & {$[1.13 ; 4.75]$} & 0.022 \\
\hline SSA migrant women & 12.5 & & 0.68 & {$[0.41 .1 .12]$} & 0.127 & 20.9 & & 3.51 & {$[2.05 ; 6.02]$} & $<0.001$ \\
\hline Non-IDU non-African men & 12.1 & & 0.78 & {$[0.53 ; 1.16]$} & 0.215 & 8.4 & & 1.86 & {$[1.02 ; 3.40]$} & 0.043 \\
\hline Non-IDU non-African & 17.1 & & 0.97 & {$[0.66 ; 1.42]$} & 0.869 & 13.0 & & 3.16 & {$[1.92 ; 5.21]$} & $<0.001$ \\
\hline \multicolumn{11}{|l|}{ women } \\
\hline \multicolumn{11}{|l|}{ Household composition } \\
\hline Single without children & 15.5 & 0.949 & & & & 6.8 & 0.001 & 1 & . & . \\
\hline Single with children & 12.9 & & & & & 16.5 & & 1.12 & {$[0.59 ; 2.14]$} & 0.725 \\
\hline Couple with children & 14.9 & & & & & 14.7 & & 1.35 & {$[0.78 ; 2.32]$} & 0.276 \\
\hline Couple without children & 13.8 & & & & & 5.4 & & 0.85 & {$[0.48 ; 1.48]$} & 0.550 \\
\hline Other situation & 15.0 & & & & & 10.1 & & 1.03 & {$[0.68 ; 1.54]$} & 0.896 \\
\hline \multicolumn{11}{|l|}{ Educational level } \\
\hline Primary school & 23.8 & $<0.001$ & 2.41 & {$[1.53 ; 3.80]$} & $<0.001$ & 11.9 & 0.031 & 1.59 & {$[0.88 ; 2.87]$} & 0.126 \\
\hline Middle school & 17.3 & & 1.82 & {$[1.19 ; 2.79]$} & 0.006 & 10.2 & & 1.48 & {$[0.84 ; 2.59]$} & 0.171 \\
\hline High school & 11.4 & & 1.33 & {$[0.81 ; 2.20]$} & 0.257 & 7.7 & & 1.16 & {$[0.61 ; 2.22]$} & 0.639 \\
\hline 2 years university degree & 10.7 & & 1.20 & {$[0.70 ; 2.04]$} & 0.501 & 6.4 & & 1.26 & {$[0.63 ; 2.52]$} & 0.513 \\
\hline$>2$ years university degree & 8.5 & & 1 & . & . & 5.3 & & 1 & . & . \\
\hline \multicolumn{11}{|l|}{ Number of relatives or } \\
\hline \multicolumn{11}{|l|}{ friends } \\
\hline $0-5$ & 19.2 & 0.014 & 1 & . & . & 11.4 & 0.024 & 1 & . & . \\
\hline $6-7$ & 16.5 & & 0.97 & {$[0.70 ; 1.33]$} & 0.825 & 9.6 & & 0.76 & {$[0.50 ; 1.16]$} & 0.198 \\
\hline 8-10 & 13.3 & & 0.91 & {$[0.65 ; 1.26]$} & 0.548 & 8.4 & & 0.86 & {$[0.55 ; 1.33]$} & 0.485 \\
\hline
\end{tabular}


$>11$

Illegal substance use in

the month

No

Yes

Tobacco consumption

Non smokers

Past smokers

Current smokers

Alcohol consumption

Abstinence

Low/moderate drinking

Heavy drinking

Body mass index

Underweight

Norma Iweight

Overweight

Obesity

Level of physical activity

Low

Medium

High

\section{Future outlook}

Low

Neutral

High

Period of HIV diagnosis

Before 1996

1996-2003

After 2003

\section{Disturbance from HIV}

\section{symptoms}

No

Yes

$8.6<0.001$

18.0
$0.71 \quad[0.49 ; 1.04] \quad 0.076$

5.2

$0.71 \quad[0.41 ; 1.21]$

0.20

$14.3 \quad 0.137$

18.3

$0.91 \quad[0.63 ; 1.32] \quad 0.621$

$9.6 \quad 0.002$

2.5

$0.77 \quad[0.30 ; 1.98] \quad 0.579$

$12.4 \quad 0.111$

1

$1.31 \quad[0.92 ; 1.88] \quad 0.135$

$1.13 \quad[0.74 ; 1.73] \quad 0.555$

$\begin{array}{ll}22.3 & <0.001 \\ 11.4 & \\ 14.2 & \end{array}$

1

$\begin{array}{llll}0.56 & {[0.43 ; 0.73]} & <0.001 & 9.0\end{array}$

$0.68 \quad[0.46 ; 1.00] \quad 0.049$

5.6

$\begin{array}{ccccc}25.6 & 0.016 & 1.42 & {[0.92 ; 2.21]} & 0.111 \\ 14.5 & 1 & \cdot & . \\ 12.8 & & 0.99 & {[0.72 ; 1.36]} & 0.940 \\ 16.1 & & 1.16 & {[0.71 ; 1.90]} & 0.550\end{array}$

aPRR: adjusted prevalence rate ratio, 95\% Cl: 95\% Confidence Interval, MSM: men who have sex with men, IDU: intravenous drug use, SSA: subSaharan African 


\section{Appendix}

The ANRS-Vespa2 Study Group includes France Lert (INSERM UMR-S 1018) and Bruno Spire (INSERM UMR-S 912 / ORS PACA) (scientific coordinators), Patrizia Carrieri (INSERM UMR-S 912 / ORS PACA), Rosemary Dray-Spira (INSERM UMR-S 1136), Christine Hamelin (INSERM UMR-S 1018), Nicolas Lorente (INSERM UMR-S 912 / ORS PACA), Marie Préau (INSERM UMRS 912 / ORS PACA) and Marie Suzan-Monti (INSERM UMR-S 912 / ORS PACA) with the collaboration of Marion Mora (INSERM UMR-S 912 / ORS PACA).

\section{List of participating hospitals and investigators}

Aix-en-Provence: CH Pays d'Aix (T. Allègre, P. Mours, J.M. Riou and M. Sordage); Angers: CHU Hôtel-Dieu (J.M. Chennebault, P. Fialaire and V. Rabier); Annemasse: CH Alpes-Léman (M. Froidure, D. Huguet and D. Leduc); Avignon: Hôpital Henri Duffaut (G. Pichancourt and A. Wajsbrot); Besançon: Hôpital Saint-Jacques (C. Bourdeaux, A. Foltzer, B. Hoen and L. Hustache-Mathieu); Bobigny: Hôpital Avicenne (S. Abgrall, R. Barruet, O. Bouchaud, A. Chabrol, S. Mattioni and F. Mechai); Bondy: Hôpital Jean Verdier (V. Jeantils); Bordeaux: Hôpital Saint-André (N. Bernard, F. Bonnet, M. Hessamfar, D. Lacoste, D. Malvy, P. Mercié, P. Morlat, F. Paccalin, M.C. Pertusa, T. Pistone, M.C. Receveur and M.A. Vandenhende); Boulogne-Billancourt: Hôpital Ambroise Paré (C. Dupont, A. Freire Maresca, J. Leporrier and E. Rouveix); Caen: Hôpital Clémenceau (S. Dargere, A. de la Blanchardière, A. Martin, V. Noyon and R. Verdon); $\mathrm{CH}$ de Chambéry (O. Rogeaux); Clermont-Ferrand: $\mathrm{CHU}$ Gabriel Montpied (J. Beytout, F. Gourdon and H. Laurichesse); Colombes: Hôpital Louis-Mourier (F. Meier, E. Mortier and A.M. Simonpoli); Creil: CH Laennec (F. Cordier); Créteil: CHIC (I. Delacroix, V. Garrait and B. Elharrar), Hôpital Henri Mondor (S. Dominguez, A.S. Lascaux, J.D. Lelièvre, Y. Levy and G. Melica); Dijon: Hôpital du Bocage (M. Buisson, L. Piroth and A. Waldner); Eaubonne, Hôpital Simone Veil (N. Gruat and A. Leprêtre); Garches: Hôpital Raymond-Poincaré 
(P. de Truchis, D. Le Du and J.Cl. Melchior), CH de Gonesse (R. Sehouane and D. Troisvallets), CHU de Grenoble (M. Blanc, I. Boccon-Gibod, A. Bosseray, J.P. Brion, F. Durand, P. Leclercq, F. Marion and P. Pavese); La Rochelle: Hôpital Saint-Louis (E. Brottier-Mancini, L. Faba and M. Roncato-Saberan); La Roche-sur-Yon: CHD Les Oudairies (O. Bollengier-Stragier, J.L. Esnault, S. Leautez-Nainville and P.Perré), CH de Lagny Marne-la-Vallée (E. Froguel, M. Nguessan and P. Simon); Le Chesnay: $\mathrm{CH}$ de Versailles (P. Colardelle, J. Doll, C. GodinCollet and S. Roussin-Bretagne); Le Kremlin-Bicêtre: Hôpital de Bicêtre (J.F. Delfraissy, M. Duracinsky, C. Goujard, D. Peretti and Y. Quertainmont), CH du Mans (J. Marionneau); Lens: $\mathrm{CH}$ Dr. Schaffner (E. Aissi and N. Van Grunderbeeck); Limoges: CHU Dupuytren (E. Denes, S. Ducroix-Roubertou, C. Genet and P. Weinbreck); Lyon: Hôpital de la Croix-Rousse (C. Augustin-Normand, A. Boibieux, L. Cotte, T. Ferry, J. Koffi, P. Miailhes, T. Perpoint, D. Peyramond and I. Schlienger), Hôpital Édouard-Herriot (J.M. Brunel, E. Carbonnel, P. Chiarello, J.M. Livrozet and D. Makhloufi); Marseille: Hôpital de la Conception (C. Dhiver, H. Husson, A. Madrid, I. Ravaux, M.L. de Severac, M. Thierry Mieg and C. Tomei), Hôpital Nord (S. Hakoun, J. Moreau, S. Mokhtari and M.J. Soavi), Hôpital Sainte Marguerite (O. Faucher, A. Ménard, M. Orticoni, I. Poizot-Martin and M.J. Soavi); Montpellier: Hôpital Gui de Chauliac (N. Atoui, V. Baillat, V. Faucherre, C. Favier, J.M. Jacquet, V. Le Moing, A. Makinson, R. Mansouri and C. Merle); Montivilliers, Hôpital Jacques Monod (N. Elforzli); Nantes: Hôtel-Dieu (C. Allavena, O. Aubry, M. Besnier, E. Billaud, B. Bonnet, S. Bouchez, D. Boutoille, C. Brunet, N. Feuillebois, M. Lefebvre, P. Morineau-Le Houssine, O. Mounoury, P. Point, F. Raffi, V. Reliquet and J.P. Talarmin); Nice: Hôpital l'Archet (C. Ceppi, E. Cua, P. Dellamonica, F. De Salvador-Guillouet, J. Durant, S. Ferrando, V. Mondain-Miton, I. Perbost, S. Pillet, B. ProuvostKeller, C. Pradier, P. Pugliese, V. Rahelinirina, P.M. Roger, E. Rosenthal and F. Sanderson); Orléans: Hôpital de La Source (L. Hocqueloux, M. Niang and T. Prazuck), Hôpital Porte Madeleine (P.Arsac and M.F. Barrault-Anstett); Paris: Hôpital Bichat - Claude-Bernard (M. Ahouanto, E. Bouvet, G. Castanedo, C. Charlois-Ou, A. Dia Kotuba, Z. Eid-Antoun, C. Jestin, 
K. Jidar, V. Joly, M.A. Khuong-Josses, N. Landgraf, R. Landman, S. Lariven, A. Leprêtre,

F. L'hériteau, M. Machado, S. Matheron, F. Michard, G. Morau, G. Pahlavan, B.C. Phung, M.H. Prévot, C. Rioux and P. Yéni), Hôpital Cochin-Tarnier (F. Bani-Sadr, A. Calboreanu, E. Chakvetadze, D. Salmon and B. Silbermann), Hôpital européen Georges-Pompidou (D. Batisse, M. Beumont, M. Buisson, P. Castiel, J. Derouineau, M. Eliaszewicz, G. Gonzalez, D. Jayle, M. Karmochkine, P. Kousignian, J. Pavie, I. Pierre and L. Weiss), Hôpital Lariboisière (E. Badsi, M. Bendenoun, J. Cervoni, M. Diemer, A. Durel, A. Rami and P. Sellier), Hôpital PitiéSalpêtrière (H. Ait-Mohand, N. Amirat, M. Bonmarchand, F. Bourdillon, G. Breton, F. Caby, J.P. Grivois, C. Katlama, M. Kirstetter, L. Paris, F. Pichon, L. Roudière, L. Schneider, M.C. Samba, S. Seang, A. Simon, H. Stitou, R. Tubiana and M.A. Valantin), Hôpital Saint-Antoine (D. Bollens, J. Bottero, E. Bui, P. Campa, L. Fonquernie, S. Fournier, P.M. Girard, A. Goetschel, H.F. Guyon, K. Lacombe, F. Lallemand, B. Lefebvre, J.L. Maynard, M.C. Meyohas, Z. Ouazene, J. Pacanowski, O. Picard, G. Raguin, P. Roussard, M. Tourneur, J. Tredup and N. Valin); Hôpital Saint-Louis (S. Balkan, F. Clavel, N. Colin de Verdière, N. De Castro, V. de Lastours, S. Ferret, S. Gallien, V. Garrait, L. Gérard, J. Goguel, M. Lafaurie, C. Lascoux-Combe, J.M. Molina, E. Oksenhendler, J. Pavie, C. Pintado, D. Ponscarme, W. Rozenbaum and A. Scemla), Hôpital Tenon (P. Bonnard, L. Lassel, M.G. Lebrette, T. Lyavanc, P. Mariot, R. Missonnier, M. Ohayon, G. Pialoux, M.P. Treilhou and J.P. Vincensini); Hôtel-Dieu (J. Gilquin, B. Hadacek, L. Nait-Ighil, T.H. Nguyen, C. Pintado, A. Sobel, J.P. Viard and O. Zak Dit Zbar); Perpignan: Hôpital Saint-Jean (H. Aumaître, A. Eden, M. Ferreyra, F. Lopez, M. Medus, S. Neuville and M. Saada); Pontoise: CH René Dubos (L. Blum); Quimper: Hôpital Laennec (P. Perfezou); Rennes: Hôpital de Pontchaillou (C. Arvieux, J.M. Chapplain, M. Revest, F. Souala and P. Tattevin); Rouen: Hôpital Charles-Nicolle (S. Bord, F. Borsa-Lebas, F. Caron, C. Chapuzet, Y. Debab, I. Gueit, M. Etienne, C. Fartoukh, K. Feltgen, C. Joly, S. Robaday-Voisin and P. Suel); Saint-Denis: CH Delafontaine (M.A. Khuong, J. Krausse, M. Poupard and G. Tran Van); Saint-Étienne: CHU Nord (C. Cazorla, F. Daoud, P. Fascia, A. Frésard, C. Guglielminotti and F. Lucht); Strasbourg: Nouvel hôpital civil 
(C. Bernard-Henry, C. Cheneau, J.M. Lang, E. de Mautort, M. Partisani, M. Priester and D. Rey); Suresnes: Hôpital Foch (C. Majerholc and D. Zucman); Toulon: CHI Chalucet (A. Assi and A. Lafeuillade), Hôpital Sainte-Anne (J.P. de Jaureguiberry and O. Gisserot); Toulouse: Hôpital de La Grave (C. Aquilina and F. Prevoteau du Clary), Hôpital Purpan (M. Alvarez, M. Chauveau, L. Cuzin, P. Delobel, D. Garipuy, E. Labau, B. Marchou, P. Massip, M. Mularczyk and M. Obadia); Tourcoing: CH Gustave Dron (F. Ajana, C. Allienne, V. Baclet, X. de la Tribonnière, T. Huleux, H. Melliez, A. Meybeck, B. Riff, M. Valette and N. Viget); Tours: CHRU Bretonneau (F. Bastides, L. Bernard, G. Gras and P. Guadagnin); Vandoeuvre-lès-Nancy: CHU Brabois (T. May and C. Rabaud); Vannes: CH Bretagne Atlantique (A. Dos Santos and Y. P oinsignon); and Villejuif: Hôpital Paul-Brousse, (O. Derradji, L. Escaut, E. Teicher and D. Vittecoq), CHI de VilleneuveSaint-Georges (J. Bantsima, P. Caraux-Paz and O. Patey). 